\title{
NMR Spectroscopy: A Useful Tool in the Determination of the Electrophilic Character of Benzofuroxans - Case Examples of the Reactions of Nitrobenzofuroxans with Dienes and Nucleophiles
}

\author{
M. Sebban, P. Sepulcri, C. Jovene, D. Vichard, F. Terrier and R. Goumont* \\ University of Versailles, ILV (Institut lavoisier de Versailles)
}

France

\section{Introduction}

2,1,3-Benzoxadiazoles 1 and related 1-oxides 2, commonly referred to as benzofurazans and benzofuroxans, respectively are heteroaromatic $10 \pi$-electron ring systems whose carbocyclic ring is intrinsically very susceptible to nucleophilic attack.1-9 Most importantly, the introduction of a $\mathrm{NO}_{2}$ group at $\mathrm{C}-4$ enhances the electrophilic reactivity of this ring by several orders of magnitude, making it comparable to that of a trinitro substituted benzene ring. This property has raised considerable interest in the 1970-1980's, mostly in connection with the recognition that the ease of covalent nucleophilic addition to the carbocyclic ring is responsible for the inhibitory effect exerted by some mononitrobenzofurazans and benzofuroxans on the biosynthesis of nucleic acid and protein in leucocytes, and the observed activity against leukaemia. Also much attention was directed to the $S_{N} A r$ reactivity of compounds like 4-chloro- and 4-fluoro-7-nitrobenzofurazans (3-4) which have become commonly used as fluorogenic reagents for detection and quantification of amino and thiol residues on proteins, drugs and biologically active molecules.

In the last decades, we have been engaged in an effort to investigate the reactivity of strongly electrophilic aromatic and heteroaromatic substitutions and related $\sigma$-complex processes. In this context, we discovered that some appropriate substitutions of the carbocyclic ring of benzofurazan and benzofuroxan structures enhance so much the electron-deficiency of this ring that the resulting compounds can be reasonably ranked as superelectrophilic heteroaromatics. Referring meanly to the readily accessible prototype substrates, namely 4,6-dinitrobenzofuroxan (DNBF, A), this review will highlight this behaviour which has proved to be very useful to assess the nucleophilic reactivity of extremely weak carbon base. In the same context, some remarkable reactivity sequences deriving from an aza substitution of the carbocyclic ring or a change in the nature of the annelated ring will be also emphasized with a particular focus on the behaviour of this extremely electrophilic substrates, namely 6-nitro [2,1,3] oxadiazolo [4, 5-b] pyridine 1-oxide,

* Corresponding Author 
<smiles>[R]CC(C)Cc1cccc2nonc12</smiles><smiles>O=[N+]([O-])c1ccc(F)c2nonc12</smiles>

3<smiles>[Y]c1cc([X])c2no[n+]([O-])c2c1</smiles>
A $\mathrm{X}=\mathrm{Y}=\mathrm{NO}_{2}(\mathrm{DNBF})$
B $\mathrm{X}=\mathrm{NO}_{2}, \mathrm{Y}=\mathrm{CF}_{3}$
C $\mathrm{X}=\mathrm{NO}_{2}, \mathrm{Y}=\mathrm{CN}$
D $\mathrm{X}=\mathrm{NO}_{2}, \mathrm{Y}=\mathrm{SO}_{2} \mathrm{CF}_{3}$
E $\mathrm{X}=\mathrm{CF}_{3}, \mathrm{Y}=\mathrm{NO}_{2}$
F $\mathrm{X}=\mathrm{CN}, \mathrm{Y}=\mathrm{NO}_{2}$
G $\mathrm{X}=\mathrm{SO}_{2} \mathrm{CF}_{3}, \mathrm{Y}=\mathrm{NO}_{2}$

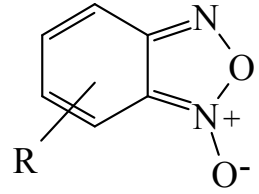

2<smiles>O=[N+]([O-])c1ccc(Cl)c2nonc12</smiles>

$\mathbf{H}$<smiles>O=[N+]([O-])c1cnc2no[n+]([O-])c2c1</smiles>

i.e. the 4-aza-6-nitro analogue of DNBF (ANBF, H). We demonstrated that highly electrophilic benzofuroxans, benzofurazans and related heteroaromatic substrates have also the potential to react in a variety of pericyclic patterns being able to contribute as dienophiles, heterodienes or carbodienes depending upon the experimental conditions and the reaction patterns at hand. Recently, it has been convincingly recognized that the exceptional electrophilic character of nitrobenzofuroxans is closely related to the low aromaticity of the carbocyclic ring. Crucial evidence for this relationship has been the discovery that the nitro-activated double bonds of this ring behave similarly to nitroalkene fragments in a variety of Diels-Alder processes, acting as dienophiles or heterodienes depending upon the reaction partner and the experimental conditions at hand.10-16 A first illustrative sequence refers to the reaction of ANBF with cyclohexadiene. Reflecting the potential 1-oxide/3-oxide interconversion of benzofuroxans through the intermediacy of an 
o-dinitroso intermediate, ${ }^{15}$ diadducts 5 resulting from normal electron-demand Diels-Alder (NEDDA) processes involving the $\mathrm{N}=\mathrm{O}$ double bonds of such intermediates as the dienophile contributors have also been isolated. Treatment of ANBF with cyclohexadiene in $\mathrm{CHCl}_{3}$ affords a 2:1 mixture of two products which were readily separated by column chromatography and isolated as pale yellow solids. The ORTEP view in Scheme 1 leaves no doubt that the major product is the diadduct 5 whose formation can only be accounted for in terms of two NEDDA processes in which the $\mathrm{N}=\mathrm{O}$ double bonds of the 0 -dinitroso intermediate 6 play the role of the dienophiles contributors (Scheme 1). In view of the ${ }^{1} \mathrm{H}$ and ${ }^{13} \mathrm{C}$ NMR spectra, the minor product can be formulated as the cycloadducts 7 , which results from a regioselective and diastereoselective NEDDA process involving the C6-C7 double bond of $\mathbf{H}$.<smiles>[NH3+]c1cnc2no[n+]([O-])c2c1</smiles><smiles>[131In][131I-]</smiles>

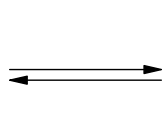<smiles>C1=CCCC=CC1</smiles>

7<smiles>O=Nc1cc([N+](=O)[O-])cnc1N=O</smiles><smiles>Cc1cc2no[n+]([O-])c2nn1</smiles><smiles>O=[N+]([O-])c1cnc(N2OC3C=CC2C3)c(N2OC3C=CC2CC3)c1</smiles>

5

Scheme 1. Diels-Alder Trapping of the o-dinitroso intermediate 6.

Some selected interactions will be presented in the first part of this review to illustrate that versatile and synthetically very promising Diels-Alder reactivity. It will be shown that NMR is a useful tool to determine the regioselectivity and the stereochemistry of the pericyclic processes. In many cases, the finding of characteristic couplings and/or signals with typical chemical shifts allows a fast determination of the regioselectivity of the Diels-Alder reactions. A short discussion of the NMR chemical shifts of the starting neutral materials (AH) will show the influence of the substituent and of the position of this substituent on the chemical shifts. In some cases, ${ }^{15} \mathrm{~N}$ labelling of nitro group has been used to determine unambiguously chemical assignments.

The considerable interest in the study of the high susceptibility of nitrobenzofuroxans to undergo covalent addition or substitution processes has led to a numerous synthetic, analytical and biological applications. A prototype example of this behaviour are the facile carbon-carbon coupling reactions of 4,6-dinitrobenzofuroxan (DNBF, A) - the reference compound in the series - with a number of benzenoid aromatics (phenols, anilines) or $\pi$ excessive heteroaromatics (pyrroles, indoles, thiophenes...) whose carbon basicities are associated with large negative $\mathrm{pk}_{\mathrm{a}}$ values. In all of these reactions, covalent addition takes 
place at C-7 of the carbocyclic ring of DNBF to give stable $\sigma$-adducts of type 8 or $\mathbf{9}$. Quantitative evaluation of thermodynamic reactivity is afforded from a comparison of $\mathrm{pK}$ values for $\mathrm{H}_{2} \mathrm{O}$ addition to yield the respective $\sigma$-complexes, for example $\mathbf{C}-\mathbf{A}, \mathbf{O H}$.<smiles>O=[N+]([O-])c1cc([N+](=O)[O-])c2no[n+]([O-])c2c1</smiles>

DNBF, $\mathbf{A}$<smiles>O=[N+]([O-])C1=CC([N+](=O)[O-])c2no[n+]([O-])c2[C@H]1O</smiles>

C-A,OH<smiles>COc1ccc(C2C([N+](=O)[O-])=CC(=[N+]([O-])[O-])c3no[n+]([O-])c32)c(OC)c1</smiles>

8<smiles>Cn1cc([C@H]2C([N+](=O)[O-])=CC(=[N+]([O-])[O-])c3no[n+]([O-])c32)c2ccccc21</smiles>

9

Thus the $\mathrm{pK}_{\mathrm{a}}^{\mathrm{H}_{2} \mathrm{O}}$ value for hydration of 4,6-dinitrobenzofuroxan (DNBF) according to (eq. 1) is equal to 3.75 in water, as compared with a $\mathrm{pK}_{\mathrm{a}}^{\mathrm{H}_{2} \mathrm{O}}$ value of 13.43 for hydration of TNB (eq. 2 ). It is this large difference in the thermodynamic ease of $\sigma$-complexation of DNBF and $\mathrm{TNB}$, which has been the starting point for the discovery of a superelectrophilic dimension in the field of $\sigma$-complexation processes. On this basis, DNBF $\mathbf{A}$ and some related derivatives (B-H) have been termed superelectrophiles.1,2<smiles>[R]c1cc([R])c2no[n+]([O-])c2c1</smiles><smiles>[R]C1=CC([R])=C2NO[N+]([O-])=C2C1[NH]</smiles>

$\mathrm{R}, \mathrm{R}^{\prime}=\mathrm{EWG}$<smiles>O=[N+]([O-])c1cc([N+](=O)[O-])cc([N+](=O)[O-])c1</smiles>

TNB<smiles></smiles>

TNB,OH

The second part of this review will be closely related to the structure of $\sigma$-complexes and to the role of the various substituents in the stabilization of the negative charge. Interestingly, their inductive or mesomeric effect will be discussed in terms of NMR chemical shifts. Indeed, the variation of the chemical shift on going from the starting neutral materials $(\mathbf{A}-\mathbf{H})$ to the $\sigma-$ complexes is a nice reflection of the electron-withdrawing effect of the substituent (eq. 3, EWG $=$ electron-withdrawing group). The special case of the trifluoromethanesulfonyl $\left(\mathrm{SO}_{2} \mathrm{CF}_{3}\right)$ group will be extensively discussed. 
<smiles>[R]c1cc([R])c2no[n+]([O-])c2c1</smiles><smiles>[14CH3]</smiles>

$\mathrm{R}, \mathrm{R}^{\prime}=\mathrm{EWG}$<smiles>[R]C1=CC([R])=C2NO[N+]([O-])=C2[C@H]1[NH]</smiles>

\section{NMR investigation of substituted benzofuroxans and benzofurazans}

The ${ }^{1} \mathrm{H}$ NMR spectra of these heterocycles are characterized by two deshielded protons at around $9 \mathrm{ppm}$. The signals of these two protons are, in the most cases, doublets with a coupling constant from $1 \mathrm{~Hz}$ to $2 \mathrm{~Hz}$, depending of the position and of the nature of the substituent (see Table 1). Interestingly, the signal of $\mathrm{H}_{7}$ is at lower field than that of $\mathrm{H}_{5}$. But it has to be noticed that the position of these signals are largely dependent of the solvent and unambiguous attributions can be performed using ${ }^{15} \mathrm{~N}$ labelling of nitro groups as it was the case for DNBF (A). ${ }^{17}$ The ${ }^{1} \mathrm{H}$ spectrum of DNBF (A) shows the $\mathrm{H}_{\mathrm{A}}$ and $\mathrm{H}_{\mathrm{X}}$ doublets of the AX system at 9.27 and $8.94 \mathrm{ppm}$, respectively, in dimethylsulfoxide (DMSO, $\mathrm{J}_{\mathrm{AX}}=1.9 \mathrm{~Hz}$ ). On ${ }^{15} \mathrm{~N}$ labelling of the 6- $\mathrm{NO}_{2}$ group, the $\mathrm{H}_{\mathrm{A}}$ and $\mathrm{H}_{\mathrm{X}}$ resonances show coupling with the nitrogen atom and coupling constant may be readily determined from the spectra $\left(\mathrm{J}_{\mathrm{N} 6 \mathrm{HA}}=\right.$ $2.4 \mathrm{~Hz}$ and $\mathrm{J}_{\mathrm{N} 6 \mathrm{HX}}=1.6 \mathrm{~Hz}$ ). On further ${ }^{15} \mathrm{~N}$ labelling at the 4- $\mathrm{NO}_{2}$ group, the $\mathrm{H}_{\mathrm{A}}$ resonance remains unaffected while that of $\mathrm{H}_{\mathrm{X}}$ undergoes an additional splitting: $\mathrm{J}_{\mathrm{N} 4 \mathrm{HX}}=2.9 \mathrm{~Hz}$. These observations show unambiguously that $\mathrm{H}_{\mathrm{A}}$ is $\mathrm{H}_{7}$ and $\mathrm{H}_{\mathrm{X}}$ is $\mathrm{H}_{5}$ in DMSO. Similar experiments have been carried out in various solvents (Table 2). In THF and acetone, it is the high field resonance of the observed $A X$ or $A B$ patterns, respectively, that is split on the ${ }^{15} \mathrm{~N}$ labelling of the 4- $\mathrm{NO}_{2}$ group. That indicates a sequence of the $\mathrm{H}_{5}$ and $\mathrm{H}_{7}$ resonances in these solvents that is the same as that found in DMSO. In contrast, it is the $\mathrm{H}_{\mathrm{A}}$ resonances that is affected by labelling the $4-\mathrm{NO}_{2}$ group in nitromethane, methylene chloride, chloroform, benzene and acetonitrile. This shows that the low field doublet of the AX (or AB) system is ascribable to $\mathrm{H}_{5}$ in these solvents. A particular situation is found in methanol where the two protons have quite identical chemical shifts.

\begin{tabular}{|c|c|c|c|c|}
\hline Compounds & $\mathbf{H}_{\mathbf{5}}$ & $\mathbf{H}_{\mathbf{7}}$ & $\mathbf{C F}_{3}{ }^{*}$ & Coupling constants $\mathbf{( H z )}$ \\
\hline $\mathbf{A}$ (DNBF) & 8.94 & 9.27 & - & ${ }^{4 \mathrm{~J}_{5 / 7}}=1.9$ \\
\hline $\mathbf{B}$ & 8.74 & 8.87 & -61.4 & ${ }^{4} \mathrm{~J}_{5 / 7}={ }^{4} \mathrm{~J}_{5 / \mathrm{F}} 1.2$ \\
\hline C & 8.92 & 9.10 & - & - \\
\hline D & 8.60 & 9.40 & -76.2 & - \\
\hline E & 8.70 & 9.07 & -61.7 & ${ }^{4 J_{5 / F}}=1.1$ \\
\hline F & 9.03 & 9.11 & - & ${ }^{4} \mathrm{~J}_{5 / 7}=1.5$ \\
\hline G & 8.70 & 9.21 & -76.9 & ${ }^{4} \mathrm{~J}_{5 / 7}=1.8$ \\
\hline
\end{tabular}

*Internal reference: $\mathrm{CFCl}_{3}$

Table 1. ${ }^{1} \mathrm{H}$ NMR data for the Benzofuroxans A-G (DMSO-d6) 


\begin{tabular}{|c|c|c|}
\hline solvent & $\mathbf{H}_{5}$ & $\mathbf{H}_{7}$ \\
\hline DMSO & 8.94 & 9.27 \\
\hline THF & 9.04 & 9.16 \\
\hline Acetone & 9.11 & 9.14 \\
\hline Methanol & 9.07 & 9.07 \\
\hline Nitromethane & 9.14 & 8.96 \\
\hline Acetonitrile & 8.98 & 8.90 \\
\hline Methylene chloride & 9.13 & 8.86 \\
\hline chloroform & 9.12 & 8.82 \\
\hline benzene & 8.08 & 7.29 \\
\hline
\end{tabular}

Table 2. Solvent effect on ${ }^{1} \mathrm{H}$ NMR data for ${ }^{15} \mathrm{~N}$ labelled DNBF
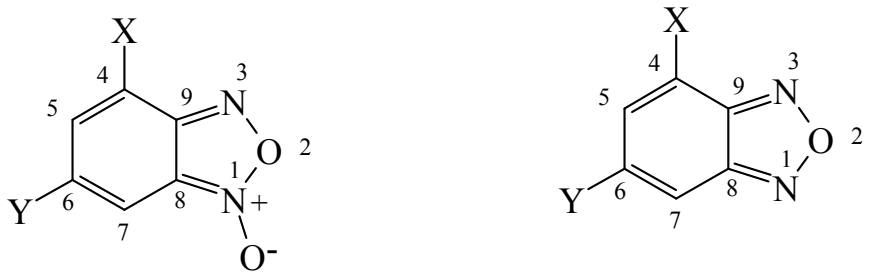
A $\mathrm{X}=\mathrm{Y}=\mathrm{NO}_{2}(\mathrm{DNBF})$
I $\mathrm{X}=\mathrm{Y}=\mathrm{NO}_{2}(\mathrm{DNBZ})$
B $\mathrm{X}=\mathrm{NO}_{2}, \mathrm{Y}=\mathrm{CF}_{3}$
J $\mathrm{X}=\mathrm{NO}_{2}, \mathrm{Y}=\mathrm{CF}_{3}$
C $\mathrm{X}=\mathrm{NO}_{2}, \mathrm{Y}=\mathrm{CN}$
K $\mathrm{X}=\mathrm{NO}_{2}, \mathrm{Y}=\mathrm{CN}$
D $\mathrm{X}=\mathrm{NO}_{2}, \mathrm{Y}=\mathrm{SO}_{2} \mathrm{CF}_{3}$
L $\mathrm{X}=\mathrm{NO}_{2}, \mathrm{Y}=\mathrm{SO}_{2} \mathrm{CF}_{3}$
E $\mathrm{X}=\mathrm{CF}_{3}, \mathrm{Y}=\mathrm{NO}_{2}$
M $\mathrm{X}=\mathrm{CF}_{3}, \mathrm{Y}=\mathrm{NO}_{2}$
F $\mathrm{X}=\mathrm{CN}, \mathrm{Y}=\mathrm{NO}_{2}$
N $\mathrm{X}=\mathrm{CN}, \mathrm{Y}=\mathrm{NO}_{2}$
G $\mathrm{X}=\mathrm{SO}_{2} \mathrm{CF}_{3}, \mathrm{Y}=\mathrm{NO}_{2}$

The ${ }^{13} \mathrm{C}$ NMR spectra of benzofuroxans A-F show some characteristic features. The complete ${ }^{13} \mathrm{C}$ NMR assignment of these compounds has been obtained using one- and twodimensional NMR techniques including HMQC and HMBC experiments. So, the two resonances pertaining to $C_{5}$ and $C_{7}$ are readily determined while the resonances of the $C_{9}$ and $C_{8}$ appear to be the key features of the ${ }^{13} \mathrm{C}$ NMR spectra of benzofuroxans. With chemical shift of 145 and 115 ppm, respectively, the signals of $C_{9}$ and $C_{8}$ are quite independent of the position and of the nature of the substituent (see Table 3). The position of the signal pertaining to $\mathrm{C}_{8}$ with compare to that of $\mathrm{C}_{9}$ could be explained by the mesomeric effect of the N-oxide functionality. ${ }^{17-18}$

This substituent effect has been attributed to the presence of a partial negative charge on $\mathrm{C}_{8}$ resulting from a significant contribution of the second resonance form described in Scheme 2, while $\mathrm{C}_{9}$, more distant from the $\mathrm{N}$-oxide function, remains unaffected or only slightly affected. 


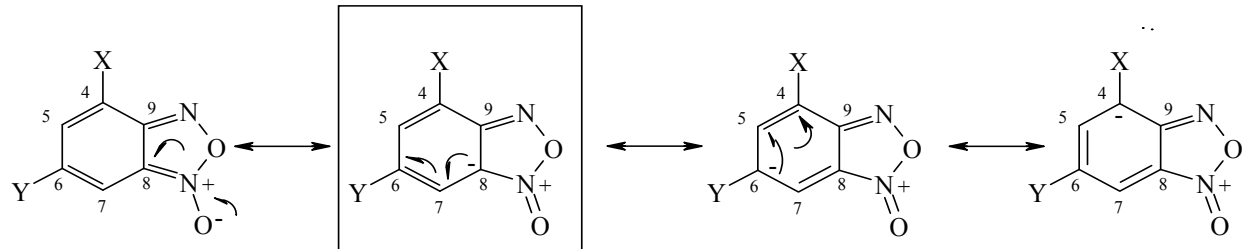

Scheme 2. Resonance forms of substituted benzofuroxans.

\begin{tabular}{|c|c|c|c|c|c|c|c|c|}
\hline Compounds & $\mathbf{C}_{4}$ & $\mathbf{C}_{5}$ & $\mathbf{C}_{6}$ & $\mathbf{C}_{7}$ & $\mathbf{C}_{8}$ & $\mathbf{C}_{9}$ & $\mathbf{C N}$ & $\mathbf{C F}_{3}$ \\
\hline A (DNBF) & 136.7 & 126.5 & 144.8 & 120.8 & 116.6 & 145.02 & - & - \\
\hline B & 137.9 & 128.1 & 127.1 & 122.5 & 116.8 & 145.2 & - & 121.9 \\
\hline C & 137.0 & 133.1 & 110.0 & 130.8 & 117.1 & 147.7 & 115.6 & - \\
\hline D & 138.1 & 128.4 & 127.6 & 132.1 & 118.0 & 145.2 & - & 119.0 \\
\hline E & 118.8 & 127.2 & 145.6 & 118.5 & 114.9 & 147.68 & - & 121.3 \\
\hline F & 102.5 & 135.9 & 146.0 & 119.0 & 114.6 & 150.2 & 112.5 & - \\
\hline G & 124.3 & 135.3 & 144.7 & 121.5 & 114.4 & 146.2 & - & 119.4 \\
\hline
\end{tabular}

Table 3. ${ }^{13} \mathrm{C}$ NMR data for the Benzofuroxans A-G (DMSO-d6)

HMBC spectra recorded for these compounds exhibited characteristic correlations. For example, two correlations between $\mathrm{C}_{9}(\delta=145 \mathrm{ppm})$ and $\mathrm{H}_{7}\left(\mathrm{~J}_{\mathrm{C} 9 \mathrm{H} 7}=5 \mathrm{~Hz}\right)$ and $\mathrm{H}_{5}\left(\mathrm{~J}_{\mathrm{C} 9 \mathrm{H} 5}=7-9\right.$ $\mathrm{Hz})$, respectively, can be observed while $\mathrm{C}_{8}(\delta=115 \mathrm{ppm})$ is only correlated with $\mathrm{H}_{7}\left(\mathrm{~J}_{\mathrm{C} 8 \mathrm{H} 7}=\right.$ 2-3 Hz). In the particular case of $\mathbf{B}$ and $\mathbf{E}$, the couplings between the fluorine atoms of the $\mathrm{CF}_{3}$ moiety and the various carbons are helpful to assign unambiguously the chemical shifts.

In most cases, the signals of the carbon atoms substituted by a $\mathrm{NO}_{2}$ group at the 4 or 6 position are very broad due to long relaxation time.

To remove the N-oxide functionality of benzofuroxans, in order to obtain the benzofurazan analogues I-N may be easily achieved using triphenylphosphine in boiling toluene. Benzofurazans are obtained in fair to moderate yields and NMR spectra have been recorded (Table 4 and 5). The removal of the N-oxide functionality is going along with the disappearance of its electron-releasing effect and has two major effects:

- the resonances of $\mathrm{H}_{5}$ and $\mathrm{H}_{7}$ pertaining to $\mathbf{I}-\mathbf{N}$ are at lower field than those of $\mathbf{A}-\mathbf{F}\left(\delta_{\mathrm{H} 5}=\right.$ 8.94 and $\delta_{\mathrm{H} 7}=9.27$ for $\mathbf{A}, \delta_{\mathrm{H} 5}=9.04$ and $\delta_{\mathrm{H} 7}=9.80$ for $\mathbf{I}$, in DMSO).

- the $C_{8}$ resonance is now at lower field than that of $C_{9}\left(\delta_{C 9}=145.0\right.$ and $\delta_{C 8}=116.6$ for $\mathbf{A}$, $\delta_{\mathrm{C} 9}=143.3$ and $\delta_{\mathrm{C} 8}=150.0$ for $\mathbf{I}$, in DMSO).

\begin{tabular}{|c|c|c|c|c|}
\hline Compounds & $\mathbf{H}_{\mathbf{5}}$ & $\mathbf{H}_{\mathbf{7}}$ & $\mathbf{C F}_{3}{ }^{*}$ & Coupling constants (Hz) \\
\hline $\mathbf{I}$ (DNBZ) & 9.04 & 9.80 & - & ${ }^{4} \mathrm{~J}_{5 / 7}=1.9$ \\
\hline $\mathbf{J}$ & 8.83 & 9.38 & -62.1 & ${ }^{4} \mathrm{~J}_{5 / 7}={ }^{4} \mathrm{~J}_{5 / \mathrm{F}} 1.2$ \\
\hline $\mathbf{K}$ & 9.04 & 9.55 & - & - \\
\hline $\mathbf{L}$ & 8.84 & 9.24 & -76.7 & ${ }^{4} \mathrm{~J}_{5 / 7}=1.3$ \\
\hline $\mathbf{M}$ & 8.62 & 9.63 & -61.8 & ${ }^{4} \mathrm{~J}_{5 / 7}={ }^{4} \mathrm{~J}_{5 / \mathrm{F}} 1.0$ \\
\hline $\mathbf{N}$ & 9.15 & 9.65 & - & ${ }^{4} \mathrm{~J}_{5 / 7}=1.8$ \\
\hline
\end{tabular}

*Internal reference: $\mathrm{CFCl}_{3}$

Table 4. ${ }^{1} \mathrm{H}$ NMR data for the Benzofurazans I-N (DMSO-d6) 


\begin{tabular}{|c|c|c|c|c|c|c|c|c|}
\hline Compounds & $\mathbf{C}_{4}$ & $\mathbf{C}_{5}$ & $\mathbf{C}_{6}$ & $\mathbf{C}_{7}$ & $\mathbf{C}_{8}$ & $\mathbf{C}_{9}$ & $\mathbf{C N}$ & $\mathbf{C F}_{3}$ \\
\hline $\mathbf{I}$ (DNBZ) & 136.8 & 125.1 & 148.7 & 122.5 & 150.0 & 143.3 & - & - \\
\hline $\mathbf{J}$ & 138.1 & 126.6 & 131.3 & 124.9 & 150.1 & 143.2 & - & 122.0 \\
\hline $\mathbf{K}$ & 137.2 & 133.3 & 115.8 & 131.3 & 149.9 & 142.9 & 114.7 & - \\
\hline $\mathbf{L}$ & 135.5 & 132.1 & 138.5 & 126.3 & 149.8 & 143.2 & - & 119.4 \\
\hline $\mathbf{M}$ & 118.1 & 126.5 & 149.1 & 120.4 & 149.3 & 145.8 & - & 121.4 \\
\hline $\mathbf{N}$ & 101.6 & 135.2 & 149.5 & 121.9 & 148.5 & 148.3 & 113.2 & - \\
\hline
\end{tabular}

Table 5. ${ }^{13} \mathrm{C}$ NMR data for the Benzofurazans I-N (DMSO-d6)

\section{NMR as a tool in the elucidation of Diels-Alder processes}

In the introduction, we have mentioned that benzofuroxans are involved in a variety of Diels-Alder processes, acting as dienophiles or heterodienes depending upon the reaction partner, the position and the nature of the substituent of the carbocyclic ring and of the experimental conditions at hand (solvent and temperature). In situ NMR studies are very informative to understand the regioselectivity of the Diels-Alder process and to collect informations on the global reaction sequence. For example, does the Diels-Alder interaction involve the formation of any detectable short-live intermediates? Many studies have been carried out at low temperature (from $-50^{\circ} \mathrm{C}$ to $-20^{\circ} \mathrm{C}$ ), using various amounts of dienes to investigate the formation of transient species which can only be characterized by NMR.

\subsection{Elucidation of the reaction of DNBF, a with cyclopentadiene ${ }^{13}$}

As it was mentioned below, the reaction of DNBF with cyclopentadiene leads to the stereoselective formation of the diadduct 12. Informations on the reaction sequence leading to 12 was obtained by carrying out a series of experiments at $-30^{\circ} \mathrm{C}$, using lower concentrations of the reagents to overcome solubility problems.
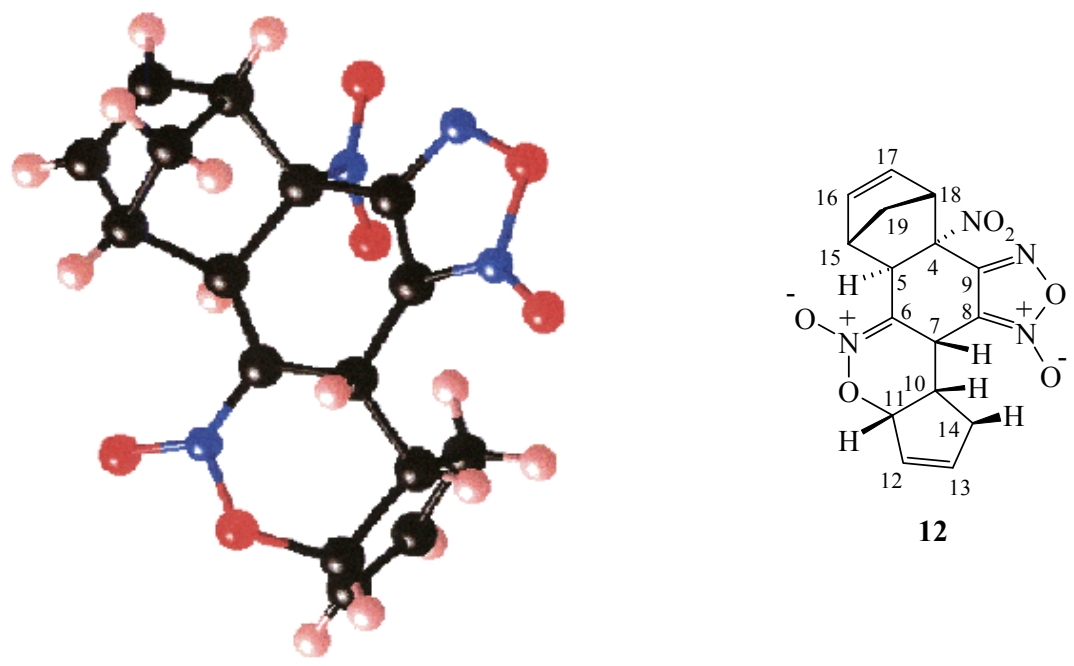

12

ORTEP view of 12 
In this instance, the spectra recorded immediately after the mixing showed the formation of two new products, $\mathbf{X}$ and $\mathbf{Y}$, in a 9:1 ratio. Raising the temperature to $-10^{\circ} \mathrm{C}$ favors the formation of $\mathbf{Y}$ at the expense of $\mathbf{X}$, both species being present in similar quantities after 30 minutes at this temperature, when the formation of $\mathbf{1 2}$ at the expense of $\mathbf{X}$ end $\mathbf{Y}$ begins to be detectable. Warming the solution to $0^{\circ} \mathrm{C}$ accelerated the appearance of $\mathbf{1 2}$, which was the only product eventually present at the completion of the reaction process. On the basis of the collected ${ }^{1} \mathrm{H}$ NMR information, there is little doubt that $\mathbf{X}$ and $\mathbf{Y}$ are the monoadducts $\mathbf{1 0}$ and 11, respectively.<smiles>O=[N+]([O-])C1=C[C@@]2([N+](=O)[O-])C[C@H]3C=C[C@H](C3)[C@H]2C1=[N+]([O-])[O-]</smiles>

10<smiles>O=[N+]([O-])C1=CC2=[N+]([O-])OC3C=CCC3C2C(=[N+]([O-])O)C1=[N+]([O-])O</smiles>

11

This implies that we are dealing with two highly regioselective and diastereoselective normal and inverse electron-demand Diels-Alder condensations. The regioselectivity at the $\mathrm{C}_{6}-\mathrm{C}_{7}$ double bond was readily demonstrated through ${ }^{15} \mathrm{~N}$ labelling of the $4-\mathrm{NO}_{2}$ group of DNBF. In this instance, the only low filed proton observed in the ${ }^{1} \mathrm{H}$ NMR spectra of $\mathbf{1 1}$ and 10 is coupled with the ${ }^{15} \mathrm{~N}$ atom indicating that this proton is $\mathrm{H}_{5}$. In addition, the observed ${ }^{3} \mathrm{~J}_{\mathrm{N} 4 \mathrm{H} 5}$ coupling constants of 3.3 and $2.6 \mathrm{~Hz}$, respectively, for $\mathbf{1 0}$ and $\mathbf{1 1}$ compare well with those previously reported for the parent DNBF molecule $\left({ }^{3} \mathrm{~J}_{\mathrm{N} 4 \mathrm{H} 5}=2.9 \mathrm{~Hz}\right) \cdot{ }^{17}$ Regarding the adduct 11, the first strong, though indirect, evidence for the proposed stereochemistry is that this structure is the only one which can be viewed as a precursor of the diadduct $\mathbf{1 2}$.

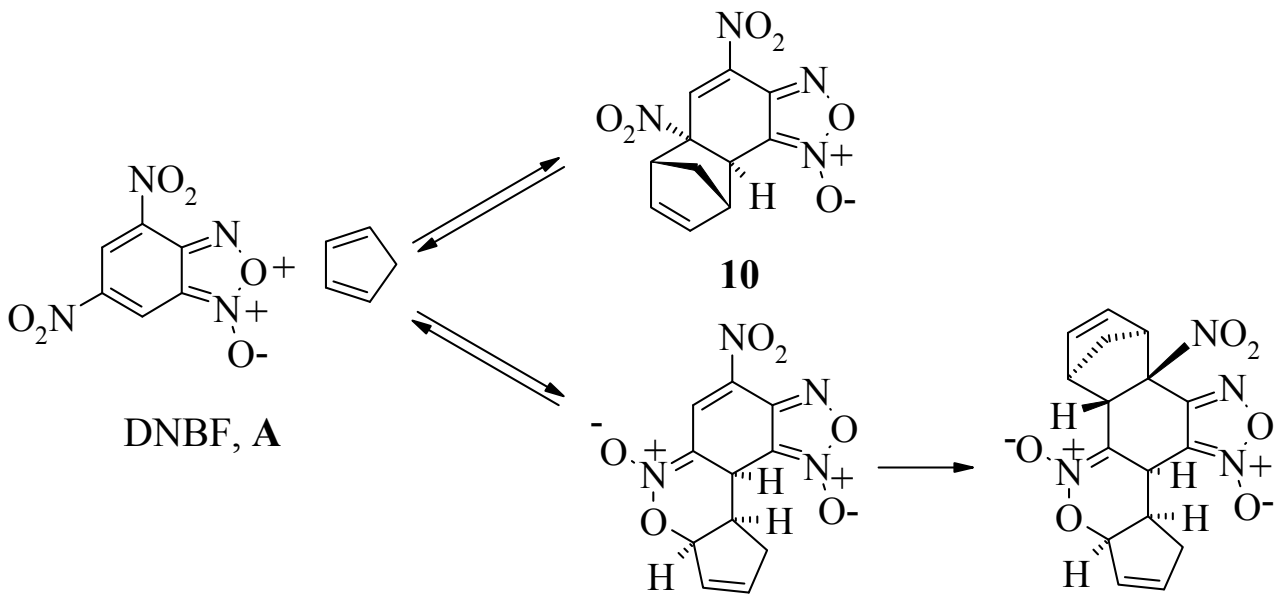

Scheme 3. Mechanism of the reaction of DNBF, A with cyclopentadiene. 
NOE experiments have been carried out which have confirmed experimentally that the $\mathrm{H}_{7}$ and $\mathrm{H}_{10}$ protons of $\mathbf{1 1}$ are in a cis arrangement, as found in $\mathbf{1 2}$. The details of this mechanism are summarized in Scheme 3.

In as much as the $\mathrm{C}_{6}-\mathrm{C}_{7}$ double bond of DNBF is involved in the two initial normal and inverse electron-demand Diels-Alder processes, the formation of the NEDDA and IEDDA adducts $\mathbf{1 0}$ and $\mathbf{1 1}$ is a clear-cut example of the potentially ambident nitroalkene Diels-Alder reactivity of DNBF. On the other hand, the preferred formation of the unsymmetrical IEDDA-NEDDA adduct 12 implies a greater dienophilic reactivity of the remaining nitroolefinic moiety in the IEDDA adduct 11 than in the NEDDA adduct 10. ${ }^{10-16}$

\subsection{Elucidation of the reaction of DNBF with 2,3-dimethylbutadiene. ${ }^{10,15}$}

Information on the reaction sequences leading to $\mathbf{1 4}$ was also obtained by recording a series of ${ }^{1} \mathrm{H}$ and ${ }^{13} \mathrm{C}$ spectra within a few minutes after mixing equimolar amounts of DNBF and 2,3-dimethylbutadiene. At this stage, the spectra showed the partial disappearance of the signals due to the starting materials and the concomitant appearance of a new set of resonances indicating the formation of a new product. The evidence is that this product can be formulated as the monoadduct 13 resulting from a regioselective NEDDA process involving the $\mathrm{C}_{6} \mathrm{C}_{7}$ double bond of the DNBF as the dienophile contributor.

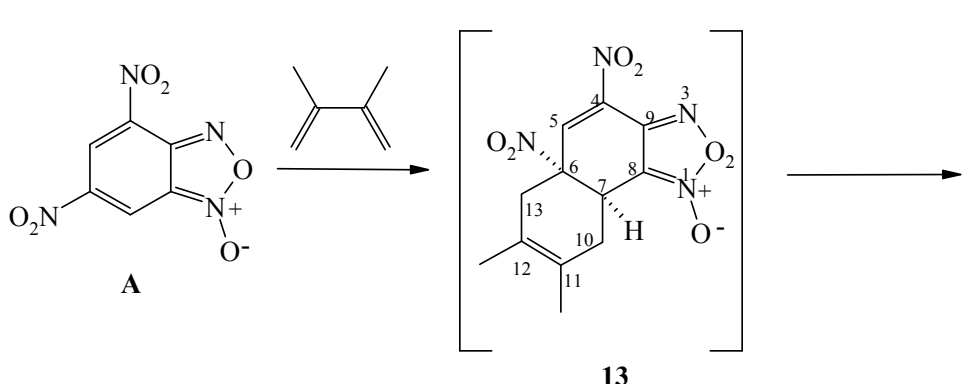

13

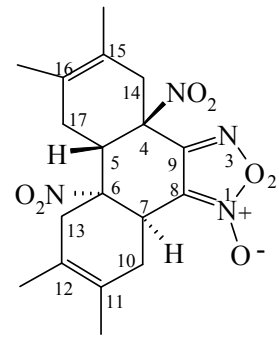

14

Scheme 4. Reaction of DNBF, A with 2,3-dimethylbutadiene.

The regioselectivity of the addition was demonstrated through ${ }^{15} \mathrm{~N}$ labelling of the $4-\mathrm{NO}_{2}$ group of DNBF. In this instance, the only low-field proton $\delta \mathrm{H}_{5}=7.54 \mathrm{ppm}$ observed in the ${ }^{1} \mathrm{H}$ spectra of 13 is coupled with the ${ }^{15} \mathrm{~N}$ atom $\left({ }^{3} \mathrm{~J}_{\mathrm{N} 4 \mathrm{H} 5}=3 \mathrm{~Hz}\right)$, confirming that this proton is $\mathrm{H}_{5}$. In contrast, the cis configuration of $\mathbf{1 3}$ could not be unambiguously confirmed from the collected NMR data. However it is clear that structure 13 with the $6-\mathrm{NO}_{2}$ group and $\mathrm{H}_{7}$ being on the same side of the two rings is the only one which can be viewed as a precursor of the diadduct 14 (Scheme 4).

\subsection{Time dependence of the ${ }^{1} \mathrm{H}$ NMR spectra of the adduct 15 obtained from the interaction of DNBF with isoprene ${ }^{10,15-16}$}

Treatment of DNBF with a large excess of isoprene (10 equiv.) in dichloromethane at room temperature for 2 days afforded two compounds in a 1/1 ratio (overall yield 90\%) which were readily separated by taking advantage of their different solubilities in pentane (Scheme 3). As 
shown by the ORTEP views of Figure 1, these two compounds correspond to diadducts which are only formed as the diastereomers 15 and 16. The stereochemistry of $\mathbf{1 5}$ in the crystal agrees well with the structural information provided by a detailed analysis of the ${ }^{1} \mathrm{H}$ and ${ }^{13} \mathrm{C}$ NMR spectra recorded in $\mathrm{CDCl}_{3}$ via COSY and HETCOR, as well as J-modulation experiments. Among other notable diagnostic features for 15, there is the observation that the disappearance of the low field proton and carbon resonances associated with the $\mathrm{C}_{4} \mathrm{C}_{5} \mathrm{C}_{6} \mathrm{C}_{7}$ fragment of the DNBF structure goes along with a strong deshielding of the two $\mathrm{sp}^{3}$ carbons $\mathrm{C}_{6}$ and $\mathrm{C}_{15}$. Both benefit from the strong electron-withdrawing inductive effect

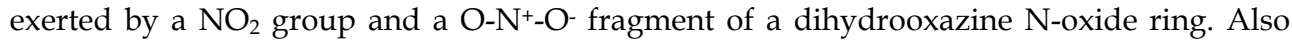
typical is the presence of the three vinylic protons $\mathrm{H}_{16}, \mathrm{H}_{17 \mathrm{a}}$ and $\mathrm{H}_{17 \mathrm{~b}}$ at 5.97, 5.45 and 5.35 ppm, respectively, in the ${ }^{1} \mathrm{H}$ spectra. NOE experiments have revealed the close space proximity of the protons $\mathrm{H}_{5}$ and $\mathrm{H}_{14 \mathrm{~b}}$ as well as of $\mathrm{H}_{7}$ and $\mathrm{H}_{10 \mathrm{~b}}$.

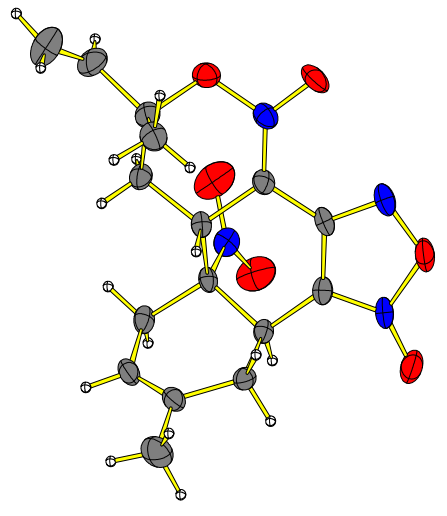

ORTEP view of $\mathbf{1 5}$

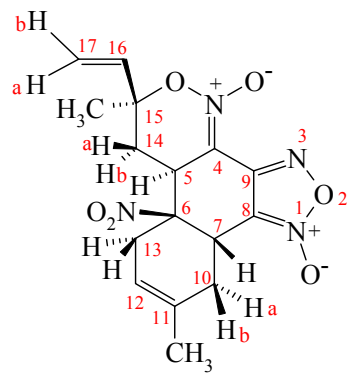

15

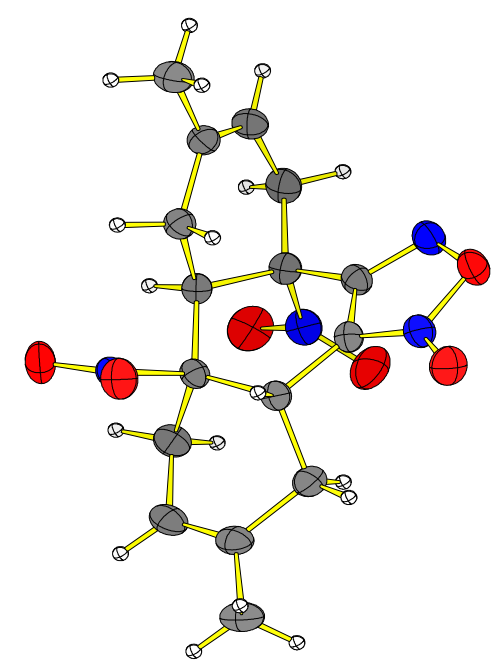

ORTEP view of $\mathbf{1 6}$

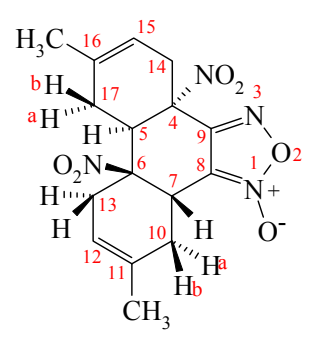

16

Fig. 1. Structures of Diels-Alder adducts 15 and 16.

Despite its remarkable stability in the solid state, the diadduct $\mathbf{1 5}$ is not the thermodynamically stable product of the reaction of DNBF with isoprene. Major changes in 
the ${ }^{1} \mathrm{H}$ and ${ }^{13} \mathrm{C}$ spectra occurred with time when a $\mathrm{CDCl}_{3}$ solution of $\mathbf{1 5}$ is kept at room temperature, with in about a month, an essentially complete disappearance of the resonances due to $\mathbf{1 5}$ and a concomitant development of new sets of proton or carbon signals ascribable to 16. At completion of the interconversion, the recorded ${ }^{1} \mathrm{H}$ and ${ }^{13} \mathrm{C}$ spectra were in fact totally identical to those obtained after dissolution of a few crystals of $\mathbf{1 6}$ in the same solvent. ${ }^{15-16}$

In accordance with its greater olefinic character, the $\mathrm{C}_{6}-\mathrm{C}_{7}$ double bond of DNBF has been found to be more reactive than its $\mathrm{C}_{4}-\mathrm{C}_{5}$ counterpart in all Diels-Alder condensation pathways so far studied. Based on this, one could anticipate that the diadducts $\mathbf{1 5}$ and $\mathbf{1 6}$ are the result of competitive inverse and normal electron-demand reactions involving the remaining nitroalkene-like $\mathrm{C}_{4}-\mathrm{C}_{5}$ fragment of an initially formed NEDDA monoadduct of type 17 (Scheme 5 and Figure 2).

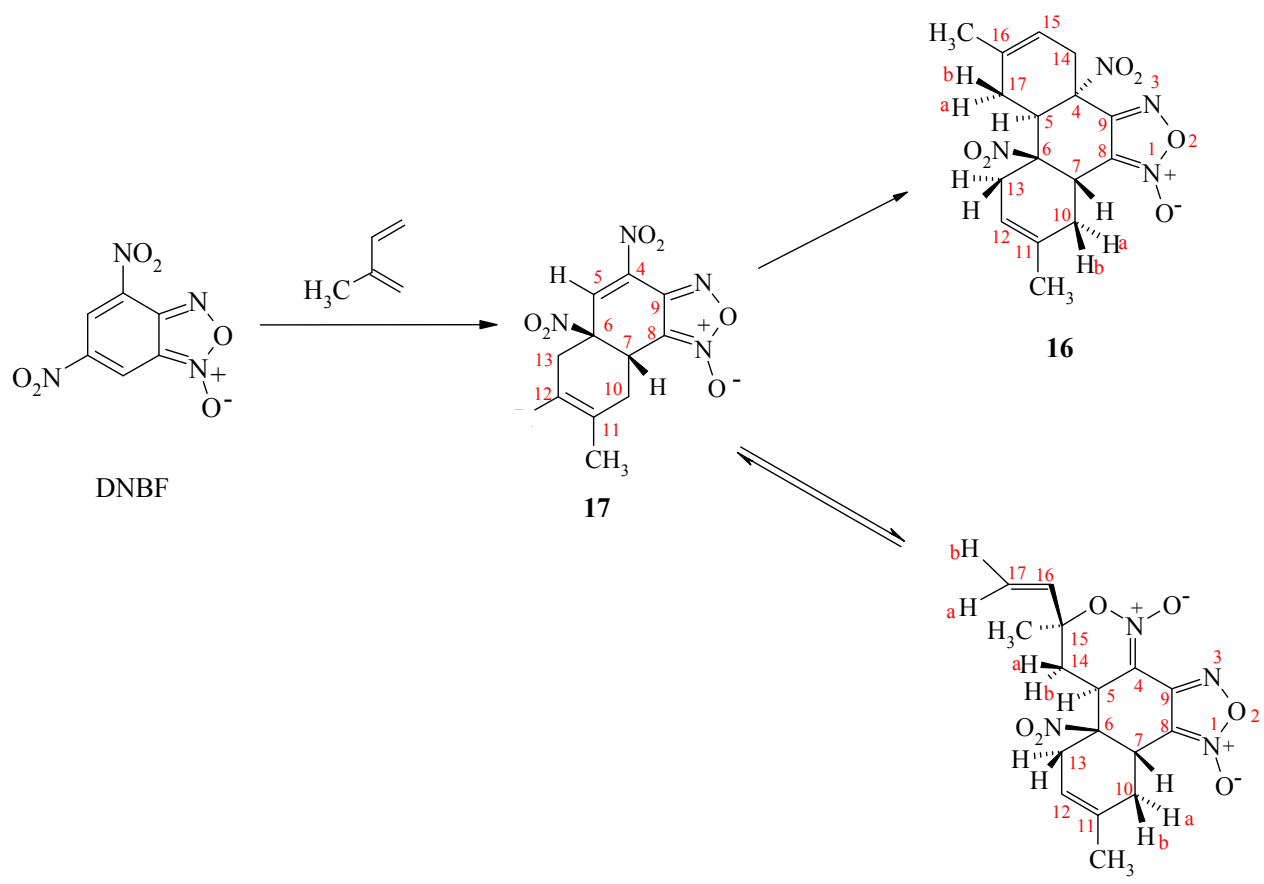

15

Scheme 5. Reaction of DNBF, A with isoprene.

Because of a more favorable thermodynamic driving force for formation of $\mathbf{1 6}$ than 15, the complete equilibrium system of Scheme 5 is progressively shifted towards the obtention of the NEDDA-NEDDA diadducts 16. There is little doubt that these species correspond to the products isolated in 1973 by Kresze and Bathelt. ${ }^{10}$ At this time, however, no attempt was made to elucidate the stereochemistry and the mechanistic course of the reactions.

That the addition of the second molecule of isoprene and 2,3-dimethylbutadiene to the monoadducts 17 occurs through competitive normal and inverse electron-demand 
pathways to give a mixture of the NEDDA-NEDDA and NEDDA-IEDDA diadducts 16 and 15 , respectively, is an unprecedented finding in the chemistry of DNBF.
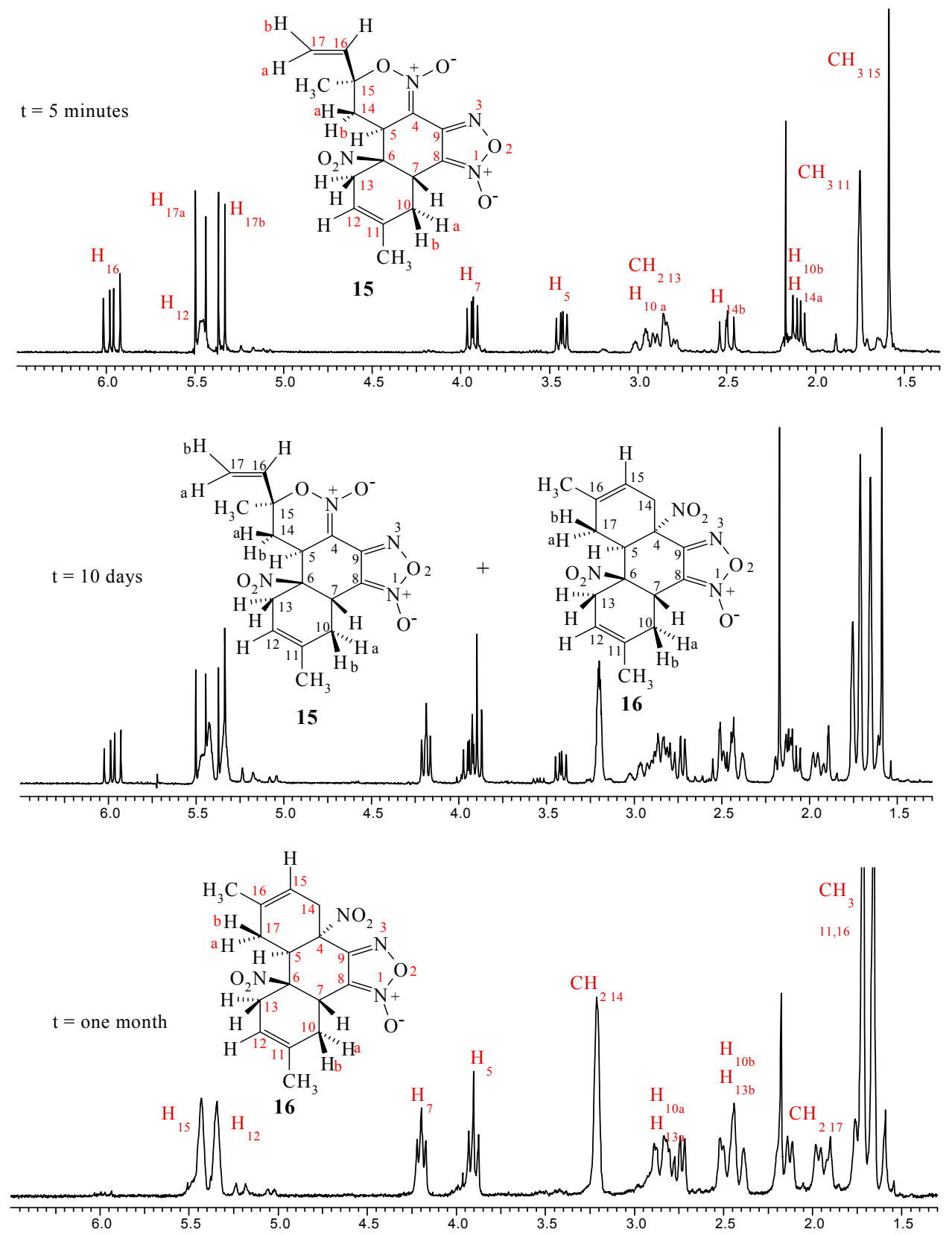

Fig. 2. Time dependence of the ${ }^{1} \mathrm{H}$ NMR spectra of a pure sample of $15 \mathrm{in} \mathrm{CDCl}_{3}$. 
The comprehensive and extensive study of the interactions between benzofuroxans and various dienes (cyclic or linear) highlights characteristic NMR data allowing to quickly determine if an adduct is the result of a Normal Electronic Demand Diels-Alder (NEDDA) reaction or of an Inverse Electronic Demand Diels-Alder (IEDDA) reaction. For example, for an IEDDA adducts, the ${ }^{1} \mathrm{H}$ NMR spectra show a deshielded signal at 6 ppm typical of $\mathrm{H}_{11}$ and a multicoupled signal at $4 \mathrm{ppm}$ typical of $\mathrm{H}_{10}$ (see Figure 3) while ${ }^{13} \mathrm{C}$ NMR spectra show that the signals pertaining to carbon $7,10,14$ are found to be at higher field in the case of IEDDA adducts than in the case of NEDDA adducts. For these latter adducts, the ${ }^{1} \mathrm{H}$ NMR spectra exhibited broad signals at 3.5 ppm pertaining to $\mathrm{H}_{10}$ and $\mathrm{H}_{13}$ (Figure 3).

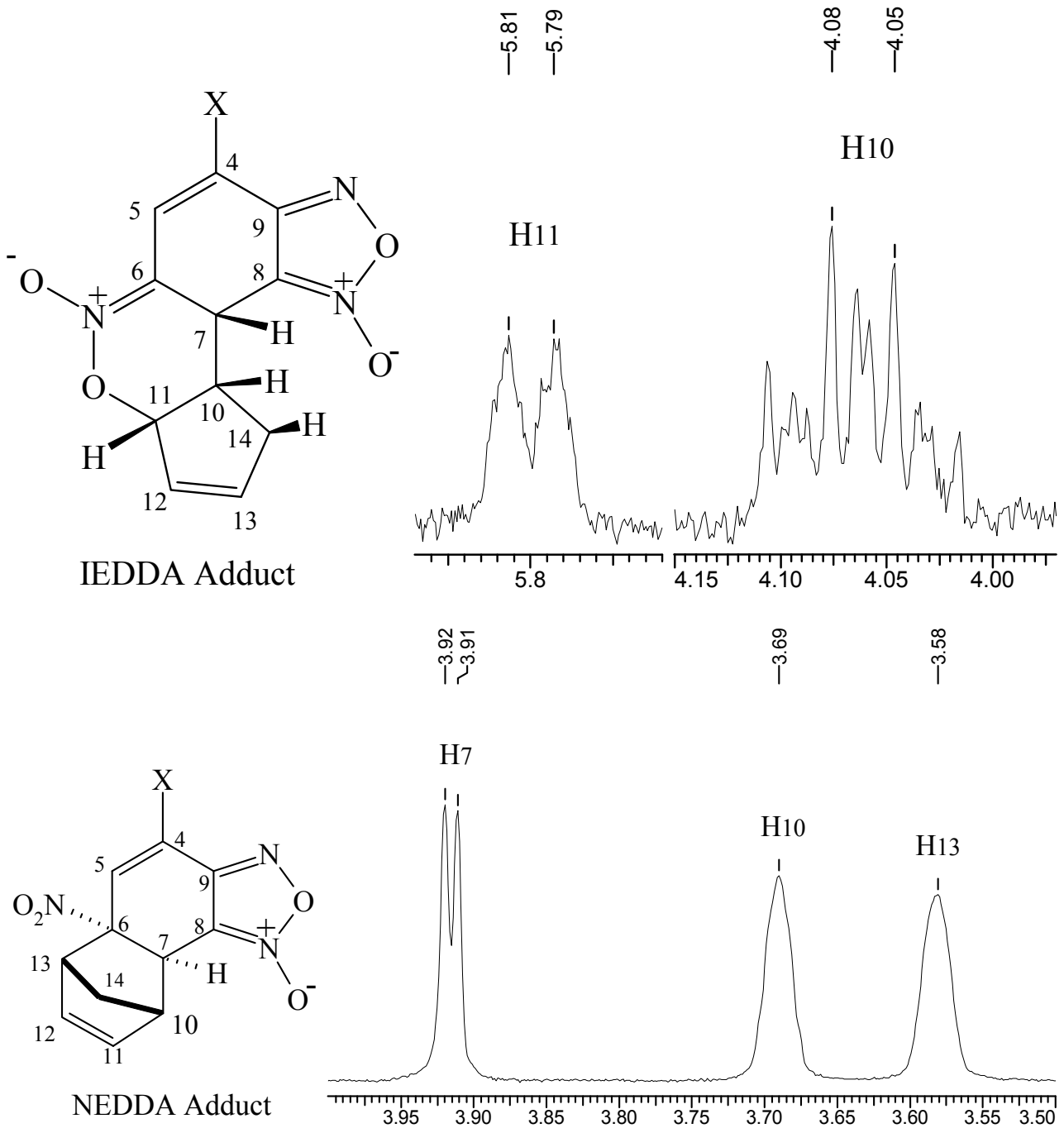

Fig. 3. Characteristic signals of Diels-Alder Adducts. 


\section{NMR in the study of the stability of $\sigma$-complexes}

Besides the potentiality of the versatile behaviour of DNBF in terms of new synthetic approaches to heterocyclic chemistry, the results obtained are in themselves evidence that the carbocyclic ring of this superelectrophilic heterocycle has a poor aromatic character relative to TNB. This suggests the existence of a significant relationship between aromaticity on the one hand, electrophilicity in $\sigma$-complex formation and pericyclic reactivity on the other hand.

Benzofuroxans A-H represent a class of neutral 10- $\pi$-electron deficient heteroaromatic substrates which exhibit an extremely high electrophilic character in many covalent nucleophilic addition and substitution processes. ${ }^{13-18}$ More importantly, DNBF, A reacts quantitatively at room temperature with such weak carbon $\pi$-nucleophiles, as benzenoid aromatics (phenols, anilines) or $\pi$-excessive heteroaromatics (indoles, pyrroles, thiophenes) to afford stable anionic C-bonded $\sigma$-adducts which are formally the products of $S_{E} A r$ substitution on the benzene or hetarene ring. Coupling to weakly activated enolic double bonds is also a process that is readily achieved with DNBF, A. Based on these findings, DNBF, A can be used as a convenient probe to assess the C-basicity of a number of very weak carbon nucleophiles, e.g. anilines, 3-aminothiophenes....

\subsection{Regioselectivity of the covalent nucleophilic addition to DNBF, A}

The addition of sodium hydroxide solution to a solution of DNBF, $\mathbf{A}$ resulted in the immediate and quantitative formation of a $\sigma$-complex 18, which can be seen as the two regio-isomeric Meisenheimer complexes 18a or $\mathbf{1 8 b}$. Many NMR studies have been carried out to determine accurately the structure of this salt. ${ }^{19-21}$

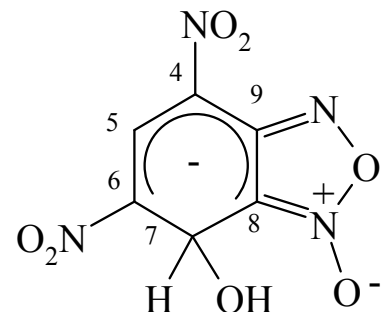

$18 \mathbf{a}$

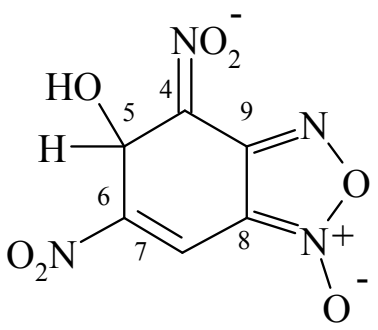

$18 \mathrm{~b}$

${ }^{1} \mathrm{H}$ nmr spectra exhibit three signals at $\delta=8.93,6.20$ (doublet, $\mathrm{J}=7 \mathrm{~Hz}$ ) and 6.55 (doublet, $\mathrm{J}=$ $7 \mathrm{~Hz}$ ) ppm. When the salt is prepared with deuterium oxide, only two signals at 8.93 and $6.20 \mathrm{ppm}$ (doublets, $\mathrm{J}=1 \mathrm{~Hz}$ ) are obtained. The use of the deuterated salts permits assignments of the chemical shifts for all protons (structures 19 and 20).

Unfortunately structures $\mathbf{1 8 a}$ and $\mathbf{1 8 b}$ are both consistent with the NMR data and it's not possible to discriminate between the two structures on this basis. Moreover, interconversion between 18a and $\mathbf{1 8 b}$ may exist in solution and is possible by two different pathways. One 
path is by a reversible hydroxylation at the 5- and 7-position (path a, scheme 6) and the other path involves a Boulton-Katritzky rearrangement (path b, Scheme 6).<smiles>CC1=C([N+](=O)[O-])C(C)(C)C(I)C1=[N+]([O-])[O-]</smiles>

$\mathrm{Hb} \mathrm{OHc}$

19

$$
\begin{aligned}
& \mathrm{H}_{\mathrm{a}}=8.97 \mathrm{ppm} \\
& \mathrm{H}_{\mathrm{b}}=6.20 \mathrm{ppm}(\mathrm{J}=7 \mathrm{~Hz}) \\
& \mathrm{H}_{\mathrm{c}}=6.55 \mathrm{ppm}(\mathrm{J}=7 \mathrm{~Hz})
\end{aligned}
$$<smiles>O=[N+]([O-])c1cc([N+](=O)[O-])c2no[n+]([O-])c2c1O</smiles><smiles>C=C=C</smiles><smiles></smiles>

$18 \mathbf{a}$

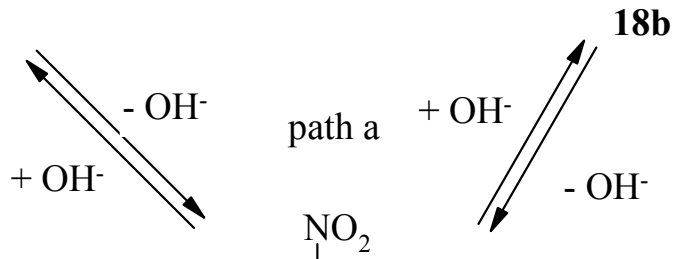<smiles></smiles>

A

Scheme 6. Interconversion between $\mathbf{1 8 a}$ and $\mathbf{1 8 b}$. 
The NMR spectra indicate only one product. If a second substance is present, its NMR spectrum is identical with the other or is present in too small amount to be detectable or the two are exchanging at a rapid state. However, consideration of resonance forms indicates that 18a (delocalization of the negative charge into the two nitro groups) should be more stable than $\mathbf{1 8 b}$ (delocalization of the negative charge into only one nitro group). The correct structure for the Meisenheimer complex formed by the reaction of DNBF, A with aqueous base is considered to be 18a. Confirmation of this result has been further confirmed by the study of the case of nitrobenzofuroxan 21, which react very similarly with water and $\mathrm{OH}^{-}$to afford hydroxy $\sigma$-adducts in aqueous solution. An analogous situation holds in methanol when there is a remarkable analogy between the rate and equilibrium parameters governing the ambident reactivity of 4-nitrobenzofuroxan 21 according to scheme 7 in this solvent.

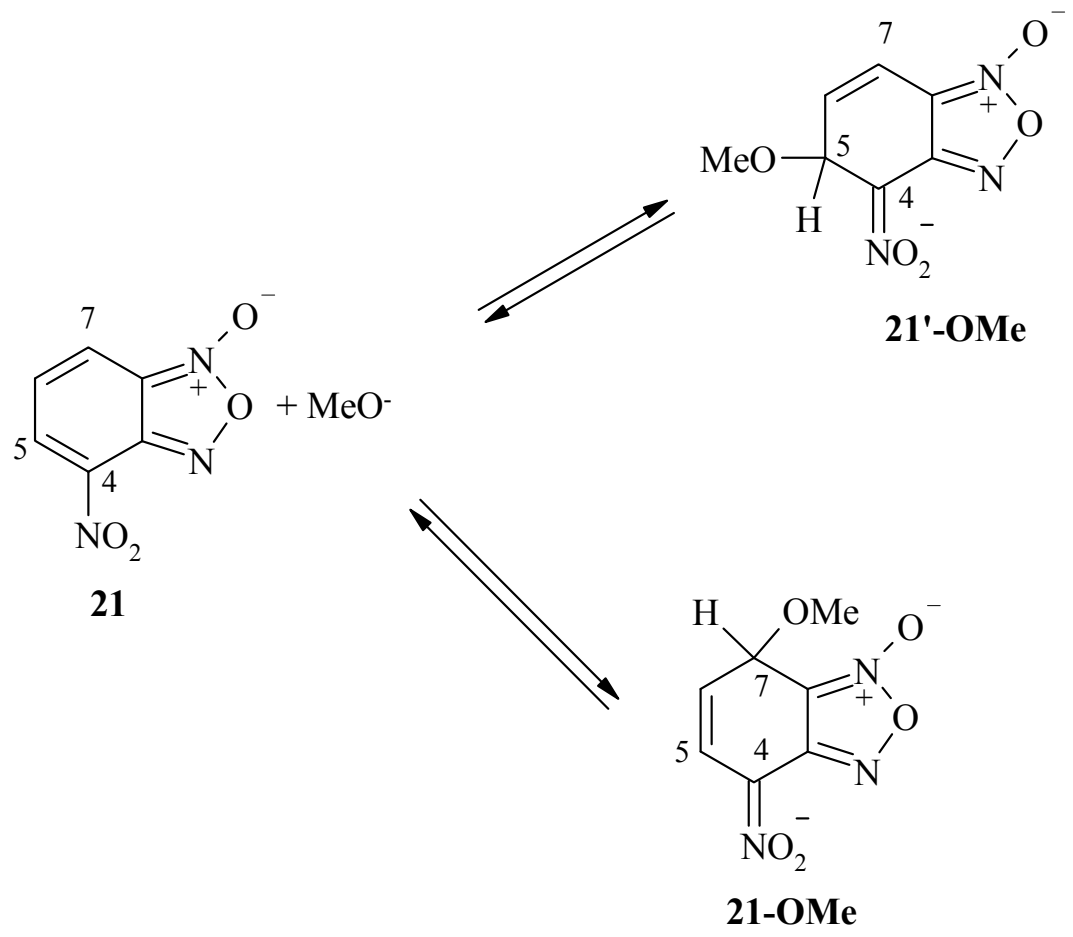

Scheme 7. Addition of methoxide ion to 4-nitrobenzofuroxan 21.

In these systems, rapid $\mathrm{MeO}$ - attack at the C-5 position of $\mathbf{2 1}$ to give $\mathbf{2 1}$ '-OMe is followed by a slow and a nearly complete isomerization of these adducts to the thermodynamically more stable 7-complexes 21-OMe. These isomers benefit from the greater efficiency of a para- than an ortho- $\mathrm{NO}_{2}$ group in delocalizing electron by resonance interaction. The formation of 21'OMe preceded the formation of the thermodynamically more stable 21-OMe adduct. Only the C-7 adduct could be observed by room temperature NMR spectroscopy, it was necessary to cool the system at low temperature prior to start of the reaction in order to detect and characterize the C-5 adduct as the product of kinetic control. In as much as it occurs with 
other nucleophiles but is restricted to $\mathbf{2 1}$, the ambident electrophilic behaviour depicted in scheme 7 is a typical feature of the chemistry of nitrobenzoxadiazoles. Because of a very fast interconversion between the C-5 and the C-7 adduct or because of a very high thermodynamic stability of the C-7 adduct, it has not been possible to detect and to characterize $18 b$, the C-5 hydroxy- $\sigma$-adduct of DNBF, even at low temperature.22-23

\subsection{NMR characterization of the $\mathrm{C}-7$ adducts of DNBF, A and its derivatives $B-\mathrm{H}^{24}$}

We have succeeded in obtaining new spectroscopic data on the Meisenheimer complexes of $\mathrm{DNBF}, \mathrm{A}$ in looking at the interaction of this compound with 2-nitropropane anion. As a major diagnostic feature in the ${ }^{1} \mathrm{H}$ NMR spectra of 22 is the $\mathrm{H}_{7}$ resonance which appears at $5.27 \mathrm{ppm}$, being in the range commonly found for many C-bonded DNBF adducts, e.g. $\delta=5.40 \mathrm{ppm}$ for 23. 3,8 The shielding of the $\mathrm{H}_{7}$ resonance $\left(\delta \mathrm{H}_{7}=9.27 \mathrm{ppm}\right.$ for $\left.\mathrm{DNBF}, \Delta \delta \mathrm{H}_{7}=4 \mathrm{ppm}\right)$ is due to the $\mathrm{sp}^{2} \rightarrow \mathrm{sp}^{3}$ rehybridization of the carbon 7 (Table 6). Also in accord with previous observations showing that the chemical shift of the $\mathrm{H}_{5}$ proton located between the two $\mathrm{NO}_{2}$ groups of the negatively charged DNBF moiety depends very little on the nature of the C-bonded structure, the $\mathrm{H}_{5}$ resonance for 22 is $\delta=8.69 \mathrm{ppm}$ and close to those found for related adducts, e.g. $\delta=$ $8.62 \mathrm{ppm}$ for $24 .^{4}$ This slight shielding may be interpreted in terms of loss of the aromatic character and of appearance of a negative charge on the DNBF moiety.<smiles></smiles>

22<smiles>Nc1ccc(C2C([N+](=O)[O-])=CC(=[N+]([O-])[O-])c3no[n+]([O-])c32)cc1</smiles>

23<smiles>COc1ccsc1C1C([N+](=O)[O-])=CC(=[N+]([O-])[O-])c2no[n+]([O-])c21</smiles> 
Regarding ${ }^{13} \mathrm{C}$ data, there are two noteworthy results: a) in accord with the $\mathrm{sp}^{2} \rightarrow \mathrm{sp}^{3}$ rehybridization resulting from the complexation of the DNBF moiety, there is a strong upfield shift of the $C_{7}$ resonance (from 120.80 for DNBF to $\sim 32 \mathrm{ppm}$ for 22); b) the substitution of 2-nitropropane $\left(\delta \mathrm{C}_{\alpha}=79.10 \mathrm{ppm}\right)$ by DNBF induces a significant low-field shift of the resonance of the $C_{\alpha}$ carbon of the nitroalkane moiety $\left(\delta C_{\alpha}=92.0 \mathrm{ppm}\right.$ for $22, \Delta \delta$ $\sim 13 \mathrm{ppm}$ ). This latter result is mainly the reflection of the fact that a negatively charged DNBF structure exerts a notable - I effect. HMBC spectra recorded for these salts exhibited characteristic correlations. For example, one correlation between $\mathrm{C}_{9}(\delta=150 \mathrm{ppm})$ and $\mathrm{H}_{5}$ $\left(\mathrm{J}_{\mathrm{C} 9 \mathrm{H} 5}=6 \mathrm{~Hz}\right)$ while $\mathrm{C}_{8}(\delta=110 \mathrm{ppm})$ is only correlated with $\mathrm{H}_{7}\left(\mathrm{~J}_{\mathrm{C} 8 \mathrm{H} 7}=9 \mathrm{~Hz}\right)$. This latter correlation is a nice support that the covalent addition of the nucleophile takes place at C-7 of the carbocyclic ring of DNBF (Table 7). ${ }^{24}$

\begin{tabular}{|c|c|c|c|c|}
\hline Compounds & $\mathbf{H}_{\mathbf{5}}$ & $\mathbf{H}_{\mathbf{7}}$ & $\mathbf{C H}_{3}$ & $\mathbf{C F}_{3}{ }^{*}$ \\
\hline $\mathbf{2 2}$ & 8.69 & 5.27 & $\begin{array}{l}1.51 \\
1.49\end{array}$ & - \\
\hline 25 & 7.68 & 4.73 & $\begin{array}{l}1.54 \\
1.44\end{array}$ & -57.3 \\
\hline 26 & 7.73 & 4.58 & $\begin{array}{l}1.61 \\
1.56\end{array}$ & - \\
\hline 27 & 8.22 & 4.56 & $\begin{array}{l}1.54 \\
1.52\end{array}$ & -78.7 \\
\hline 28 & 7.97 & 5.30 & $\begin{array}{l}1.51 \\
1.46\end{array}$ & -58.8 \\
\hline \multirow{2}{*}{29} & 8.09 & 5.30 & $\begin{array}{l}1.49 \\
1.46\end{array}$ & - \\
\hline
\end{tabular}

Table 6. ${ }^{1} \mathrm{H}$ NMR data for the adducts 22 and 25-29 (DMSO-d6)

\begin{tabular}{|l|l|l|l|l|l|l|l|l|l|l|}
\hline $\begin{array}{l}\text { Compoun } \\
\text { ds }\end{array}$ & $\mathrm{C}_{4}$ & $\mathrm{C}_{5}$ & $\mathrm{C}_{6}$ & $\mathrm{C}_{7}$ & $\mathrm{C}_{8}$ & $\mathrm{C}_{9}$ & $\mathrm{CN}$ & $\mathrm{CF}_{3}$ & $\mathrm{C}_{\alpha}$ & $\mathrm{Me}$ \\
\hline 22 & 110.6 & 133.3 & 121.0 & 41.3 & 110.1 & 149.8 & - & - & 92.1 & $\begin{array}{l}23.3 \\
23.2\end{array}$ \\
\hline 25 & 106.4 & 132.7 & 99.7 & 40.2 & 110.0 & 150.8 & - & 124.5 & 92.6 & $\begin{array}{l}24.9 \\
21.3\end{array}$ \\
\hline 26 & 108.7 & 140.4 & 80.5 & 42.5 & 109.3 & 150.0 & 121.1 & - & 92.6 & $\begin{array}{l}23.5 \\
22.9\end{array}$ \\
\hline 27 & 113.3 & 144.2 & 90.4 & 41.3 & 109.1 & 149.8 & - & 120.2 & 92.5 & $\begin{array}{l}23.0 \\
22.8\end{array}$ \\
\hline 28 & 91.0 & 134.2 & 110.9 & 41.5 & 109.6 & 151.4 & - & 123.9 & 92.7 & $\begin{array}{l}23.8 \\
23.2\end{array}$ \\
\hline 29 & 73.8 & 141.1 & 115.1 & 41.3 & 109.2 & 153.6 & 117.8 & - & 92.5 & $\begin{array}{l}23.5 \\
22.9\end{array}$ \\
\hline
\end{tabular}

Table 7. ${ }^{13} \mathrm{C}$ NMR data for the adducts 22 and 25-29 (DMSO-d6) 
All the NMR data pertaining to 22 are summarized in Tables 6 and 7 together with the NMR data of the Meisenheimer complexes deriving from benzofuroxans B-H.

The delocalization of this negative charge over the DNBF moiety and over the two nitro groups is the main factor governing the outstanding stability of these Meisenheimer complexes. What will be the effect of the replacement of a nitro group by another electronwithdrawing group on the stability of the Meisenheimer complexes?

The first message emerging from the data, recorded for $\sigma$-adducts $25-29$ and collected in Tables 6 and 7 , is that the resonances of $C_{7}$ (from 40.2 to $42.5 \mathrm{ppm}$ ), $\mathrm{C}_{8}$ (from 109.2 to 110.1 ppm), $C_{9}$ (from 149.8 to $153.6 \mathrm{ppm}$ ) and $\mathrm{C}_{\alpha}$ (from 92.1 to $92.7 \mathrm{ppm}$ ) are independent of the position and of the nature of the substituent and are consistent with those reported for the adduct 22. It could be through evaluation of the chemical shift variations brought about by the complex formation that reliable information on the structural reorganization which accompanies the formation of the $\sigma$-adduct may be obtained. Such variations $(\Delta \delta)$ are the result of a high field shift caused by the presence of the negative charge. On the basis of the above reasoning, a comparison in Table 8 of the $\Delta \delta \mathrm{H}_{5}, \Delta \delta \mathrm{C}_{4}$ and $\Delta \delta \mathrm{C}_{6}$ associated with the complexes formation is very informative regarding the structure of the $\sigma$-adducts. As can be seen, large upfield shifts of $\mathrm{H}_{5}\left(\Delta \delta \mathrm{H}_{5} \sim 0.2-1.2 \mathrm{ppm}\right)$, of $\mathrm{C}_{6}\left(\Delta \delta \mathrm{C}_{6} \sim 25-32 \mathrm{ppm}\right)$ and of $\mathrm{C}_{4}\left(\Delta \delta \mathrm{C}_{4} \sim 24-38 \mathrm{ppm}\right)$ occur upon $\sigma$-complex formation (see Table 8 ). Such $\Delta \delta$ agree well with the presence of the negative charge, with the loss of the aromatic character and with a sp $\rightarrow \mathrm{sp}^{3}$ rehybridization. The large upfield shifts of $\mathrm{C}_{6}$ for salts 25-27 and of $\mathrm{C}_{4}$ for salts 28-29 is a large reflection that the resonance forms $C_{-} Y^{-}$and $C-X-$, respectively, play a major role in the stabilization of the negative charge (Scheme 8). Because of a large inductive effect of the cyano and trifluoromethyl groups, the negative charge is retained on the $\mathrm{C}_{4}$ or on the $\mathrm{C}_{6}$ carbon. In the case of the trifluoromethanesulfonyl group, the inductive effect is larger than for the two latter groups and is going along with the smallest $\Delta \delta \mathrm{H}_{5}(0.38 \mathrm{ppm})$ and the largest $\Delta \delta \mathrm{C}_{6}(37 \mathrm{ppm})$ leaving no doubt that the $\mathrm{SO}_{2} \mathrm{CF}_{3}$ group is capable to stabilize a negative charge by a strong polarization effect. The negative charge is largely retained on the $\mathrm{C}_{6}$ carbon and is less delocalized through the carbocyclic ring.

\begin{tabular}{|c|c|c|c|}
\hline Compounds & $\Delta \boldsymbol{\delta}_{\mathbf{5}}$ & $\Delta \boldsymbol{\delta}_{\mathbf{4}}$ & $\Delta \delta \mathrm{C}_{\mathbf{6}}$ \\
\hline $\mathbf{2 2}$ & 0.25 & 26.1 & 23.8 \\
\hline $\mathbf{2 5}$ & 1.06 & 31.5 & 27.4 \\
\hline $\mathbf{2 6}$ & 1.19 & 28.3 & 29.5 \\
\hline $\mathbf{2 7}$ & 0.38 & 24.8 & 37.2 \\
\hline $\mathbf{2 8}$ & 0.73 & 27.8 & 34.7 \\
\hline $\mathbf{2 9}$ & 0.94 & 29.7 & 31.6 \\
\hline
\end{tabular}

Table 8. Changes in chemical Shifts $\left(\Delta \delta \mathrm{H}_{5}, \Delta \delta \mathrm{C}_{6}\right.$ and $\left.\Delta \delta \mathrm{C}_{4}\right)$ upon $\sigma$-complex formation in DMSO-d6 
<smiles>[Y]C1CC(=[N+]([O-])[O-])c2no[n+]([O-])c2C1C(C)(C)[N+](=O)[O-]</smiles>

$\mathrm{C}-\mathrm{NO}_{2}^{-}$

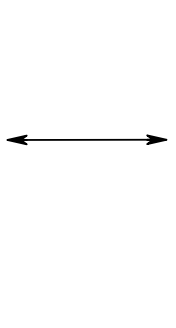

$$
\mathrm{C}-4^{-}
$$

$$
\begin{aligned}
& \mathrm{Y}=\mathrm{CF}_{3}, \mathbf{2 5} \\
& \mathrm{Y}=\mathrm{CN}, \mathbf{2 6} \\
& \mathrm{Y}=\mathrm{SO}_{2} \mathrm{CF}_{3}, \mathbf{2 7}
\end{aligned}
$$

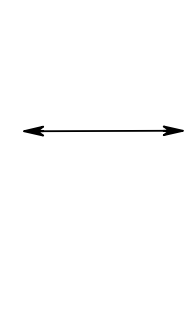<smiles>[Y]C1C=C([N+](=O)[O-])c2no[n+]([O-])c2C1C(C)(C)C</smiles>

$\mathrm{C}-\mathrm{Y}^{-}$<smiles>[X]C1=CC([N+](=O)[O-])C(C(C)(C)[N+](=O)[O-])c2c1no[n+]2[O-]</smiles><smiles></smiles><smiles>CCCCC</smiles><smiles></smiles>

$$
\begin{aligned}
& \mathrm{X}=\mathrm{CF}_{3}, \mathbf{2 8} \\
& \mathrm{X}=\mathrm{CN}, \mathbf{2 9}
\end{aligned}
$$

Scheme 8. Resonance forms of sigma-complexes 25-29.

\section{$4.3{ }^{15} \mathrm{~N}$ NMR characterization of the $\mathrm{N}$-adduct of DNBF, A with 4,5-dimethylthiazole}

Treatment of DNBF, $\mathbf{A}$ with a two-fold excess of $\mathbf{3 0}$ in acetonitrile solution, followed by addition of diethylether, resulted in the precipitation of an orange solid corresponding to the 4,5-dimethylthiazolium salt of the adduct N-30 (Scheme 9). Because of the strong acidifying effect exerted by a negatively charged DNBF moiety, ${ }^{24}$ the deprotonation of the $\mathrm{NH}_{2}{ }^{+}$group of the initially formed zwitterion $\mathbf{N}-\mathbf{3 0}$ by $\mathbf{3 0}$ acting as a base reagent is a facile process, accounting for the adduct salt $\mathbf{N}-\mathbf{3 0} ; \mathbf{3 0}, \mathbf{H}^{+}$being the thermodynamically stable product of the interaction and therefore for the need of two moles of $\mathbf{3 0}$ to drive the overall equilibrium process to completion in acetonitrile solution.

The bonding of DNBF at a nitrogen center is supported by the presence of a relatively lowfield $\mathrm{H}_{7^{\prime}}$ resonance $\left(\delta \mathrm{H}_{7^{\prime}}=6.00 \mathrm{ppm}\right)$ in the ${ }^{1} \mathrm{H} \mathrm{nmr}$ spectra. The evidence, however, is that this resonance is very sensitive to the nature of the atom or group bonded to that position, the shielding increasing with decreasing the electronegativity of the attached atom, i.e. according to the sequence $\mathrm{O}<\mathrm{N}<\mathrm{C}$. 
<smiles>Cc1nc(N)sc1C</smiles><smiles></smiles><smiles></smiles><smiles>Cc1nc(N[Pb])sc1C</smiles>

N-30<smiles>O=[N+]([O-])C1=CC(=[N+]([O-])[O-])c2no[n+]([O-])c2C1Nc1ccccc1</smiles>

\section{N-31}

On this ground, the finding of a $\mathrm{H}_{7^{\prime}}$ resonance at $6.00 \mathrm{ppm}$ and a $\mathrm{C}_{7^{\prime}}$ resonance at $46.1 \mathrm{ppm}$ leaves little doubt regarding the N-bonded structure of the DNBF adduct of 4,5-dimethyl-2aminothiazole 30. As a matter of fact, the $\mathrm{H}_{7}$ resonance of $\mathbf{N}-\mathbf{3 0}$ is very similar to that of the anionic aniline complex $\mathrm{N}-31\left(\delta \mathrm{H}_{7^{\prime}}=6.08 \mathrm{ppm}\right){ }^{3}{ }^{1} \mathrm{H}-15 \mathrm{~N}$ correlations based on long-range coupling are clearly in favour of structure $\mathbf{N}-30$. In the spectra, correlations can be observed between the exocyclic nitrogen $\mathrm{N}_{1}(\delta=87.1 \mathrm{ppm})$ and $\mathrm{H}_{7^{\prime}}(\delta=6.00 \mathrm{ppm})$, between the endocyclic nitrogen $\mathrm{N}_{3}(\delta=245.0 \mathrm{ppm})$ and the methyl group at C-4 $(\delta=2.05 \mathrm{ppm})$; concomitantly, the correlation between the endocyclic nitrogen $\mathrm{N}_{3^{\prime \prime}}(\delta=180.5 \mathrm{ppm})$ and the methyl group at C-4" $(\delta=2.08 \mathrm{ppm})$ of the thiazolium counterpart is observed (Figure 4a). This latter correlation is similar to that observed with the 4,5-dimethylaminothiazolium bromide (Figure $4 \mathrm{~b}$ ). To be noted is that all the ${ }^{15} \mathrm{~N} \mathrm{nmr}$ data collected from the various correlations are in full agreement with a recent review on the use of long-range ${ }^{1} \mathrm{H}-15 \mathrm{~N}$ correlations in the structural determination of organic compounds. ${ }^{25-26}$

The formation of the nitrogen adduct of DNBF is strongly supported by the ${ }^{15} \mathrm{~N}$ NMR and especially through the ${ }^{1} \mathrm{H}-15 \mathrm{~N}$ correlations. 


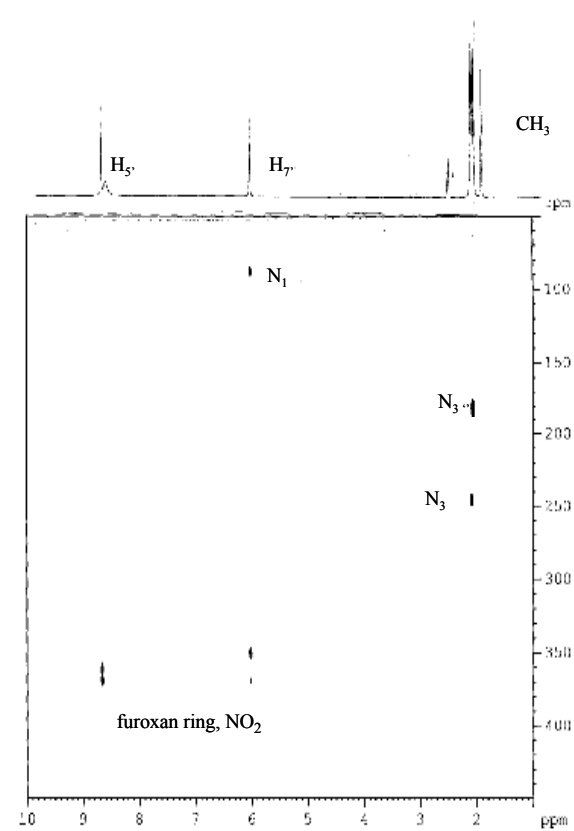

Fig. 4 a. ${ }^{1} \mathrm{H}-15 \mathrm{~N}$ correlation for the adduct $\mathrm{N}-30 ; 30, \mathrm{H}^{+}$

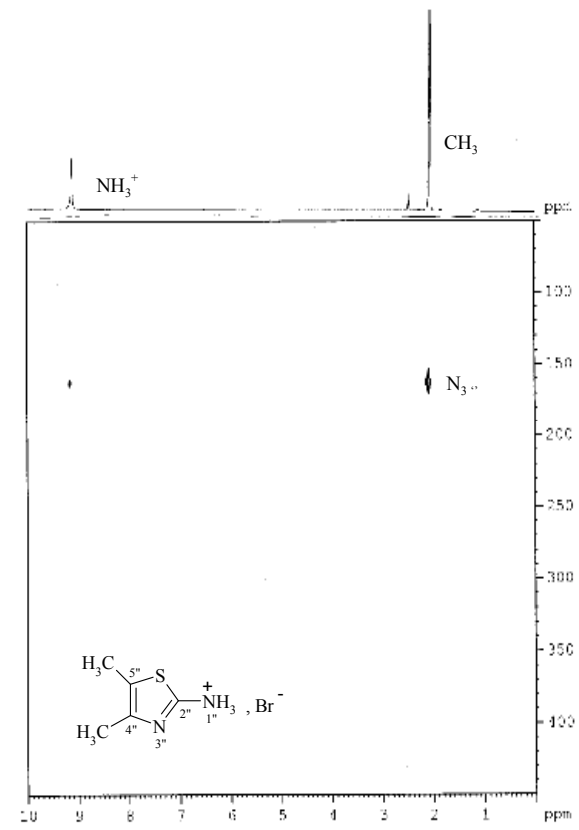

Fig. $4 \mathrm{~b} .{ }^{1} \mathrm{H}-15 \mathrm{~N}$ correlation for 4,5-dimethylaminothiazolium bromide

\section{Conclusion}

In this article we have highlighted some of the most significant examples where NMR spectroscopy brought important informations in the domain of the reactivity of benzofuroxans in synthetic applications (Diels-Alder, Meisenheimer Complexes formation). NMR strongly supports the structure of $\sigma$-complexes and informations on the capability of electron withdrawing groups to stabilize these complexes have been obtained. When $\sigma-$ complexes are stabilized by electron-withdrawing inductive effect $\left(\mathrm{CF}_{3}, \mathrm{CN}, \mathrm{SO}_{2} \mathrm{CF}_{3}\right)$, a large part of the negative charge is retained on the $\mathrm{C}_{4}$ or $\mathrm{C}_{6}$ carbon and is less delocalized through the carbocyclic ring. Moreover, the regioselectivity of the covalent nucleophilic addition can be unambiguously determined. The $\mathrm{H}_{7}$ resonance is a key feature to see if DNBF is bonded at a nitrogen $\left(\mathrm{\delta H}_{7} \sim 6 \mathrm{ppm}\right)$ or carbon $\left(\mathrm{\delta H}_{7} \sim 4 \mathrm{ppm}\right)$ center. In the case of Diels-Alder reactions, NMR appears to be a useful tool, and especially using ${ }^{15} \mathrm{~N}$ labelling, to highlight short-live species involved in complicated mechanisms.

\section{References}

[1] Terrier, F. In Nucleophilic Aromatic Displacement; Feuer, H, Ed.; VCH: New York, 1991. Terrier, F Chem. Rev. 1982, 82, 77. Buncel, E.; Dust, J. M.; Terrier, F Chem. Rev. 1995, $95,2261$. 
[2] Terrier, F; Millot, F.; Norris, W. P. J. Am. Chem. Soc. 1976, 98, 5883. Terrier, F.; Chatrousse, A. P.; Soudais, Y; Hlaibi, M. J. Org. Chem. 1984, 49, 4176. Terrier, F.; Pouet, M. J.; Kizilian, E.; Hallé, J. C.; Outurquin, F.; Paulmier, C. J. Org. Chem. 1993, 58, 4696.

[3] Strauss, M. J.; Renfrow, R. A.; Buncel, E. J. Am. Chem. Soc. 1983, 105, 2473. Buncel, E.; Renfrow, R. A.; Strauss, M. J. J. Org. Chem. 1987, 52, 488. Buncel, E.; Dust, J. M.; Manderville, R. A. J. Am. Chem. Soc. 1996, 118, 6072. Buncel, E.; Manderville, R. A.; Dust, J. M. J. Chem. Soc. Perkin Trans 2. 1997, 1019 and references therein.

[4] Crampton, M. R.; Rabbitt, L. C. J. Chem. Soc. Perkin Trans 2. 1999, 1669. Crampton, M. R.; Rabbitt, L. C.; Terrier, F. Can. J. Chem. 1999, 77, 639. Crampton, M. R.; Rabbitt, L. C. J. Chem. Soc. Perkin Trans 2. 2000, 2159. Atherton, J. H.; Crampton, M. R.; Duffield, G. L.; Stevens, J. A. J. Chem. Soc. Perkin Trans 2. 1995, 443.

[5] Kind, J.; Niclas, H. J. Synth. Commun. 1993, 23, 1569. Niclas, H. J.; Göhrmann, B. Synth. Commun. 1989, 19, 2141. Niclas, H. J.; Göhrmann, B.; Gründemann Synth. Commun. 1989, 19, 2789.

[6] Ghosh, P. B.; Ternai, B.; Whitehouse, M. W. Med. Res. Rev. 1981, 1, 159 and references therein.

[7] Lowe-Ma, C. K.; Nissan, R. A.; Wilson, W. S. J. Org. Chem. 1990, 55, 3755.

[8] Terrier, F.; Kizilian, E.; Hallé, J. C.; Buncel, E. J. Am. Chem. Soc. 1992, 114, 1740. Kizilian, E.; Terrier, F.; Chatrousse, A. P.; Gzouli, K.; Hallé, J. C. J. Chem. Soc. Perkin Trans 2. 1997, 2567. Terrier, F.; Pouet, M. J.; Hallé, J. C.; Kizilian, E.; Buncel, E. J. Phys. Org. Chem. 1998, 11, 707. Terrier, F.; Pouet, M. J.; Gzouli, K.; Hallé, J. C.; Outurquin, F.; Paulmier, C. Can. J. Chem. 1998, 76, 937.

[9] Spear, R. J.; Norris, W. P.; Read, R. W. Tetrahedron Lett. 1983, 23, 1555. Norris, W. P.; Spear, R. J.; Read, R. W. Aust. J. Chem. 1989, 36, 297.

[10] Kresze, G.; Bathelt, H.; Tetrahedron 1973, 29, 1043.

[11] Hallé, J. C.; Vichard, D.; Pouet, M. J.; Terrier, F. J. Org. Chem. 1997, 62, 7178. Pugnaud, S.; Masure, D.; Hallé, J. C.; Chaquin, P. J. Org. Chem. 1997, 62, 8687.

[12] Vichard, D.; Hallé, J. C.; Huguet, B.; Pouet, M. J.; Riou, D.; Terrier, F. Chem. Commun. 1998, 791.

[13] Sepulcri, P.; Hallé, J. C.; Goumont, R.; Riou, D.; Terrier, F. J. Org. Chem. 1999, 64, 9254. Sepulcri, P.; Goumont, R.; Hallé, J. C.; Riou, D.; Terrier, F. J. Chem. Soc. Perkin Trans. 2. 2000, 51 .

[14] Sebban, M.; Goumont, R.; Hallé, J. C.; Marrot, J.; Terrier, F. Chem. Commun. 1999, 1009. Terrier, F.; Sebban, M.; Goumont, R.; Hallé, J. C.; Moutiers, G.; Cangelosi, I. Buncel, E., J. Org. Chem. 2000, 65, 7391.

[15] Goumont, R; Sebban, M; Sepulcri, P; Marrot, J. and Terrier, F., Tetrahedron 2002, 58, 3249; Goumont, R; Sebban, M. and Terrier, F., Chem. Commun. 2002, 2110.

[16] Goumont, M. Sebban, J. Marrot, F. Terrier, ARKIVOC, 2004, 85.

[17] Terrier, F.; Hallé, J. C.; MacCormack, P. and Pouet, M. J., Can. J. Chem, 1989, 67, 50.

[18] Anet, F. A. L and Yavari, I., Org. Magn. Reson., 1976, 8, 158.

[19] Boulton, A. J. And Clifford D. P., J Chem. Soc., 1965, 5414.

[20] Norris, W. P. and Osmunden, J., J. Org. Chem. 1965, 30, 2407.

[21] Brown, W. E. and Keyes, R.T., J. Org. Chem. 1965, 30, 2452.

[22] Terrier, F; Millot, F. and Chatrousse, A. P., J. Org. Chem. 1980, 45, 2666.

[23] Terrier, F; Millot, F. ; Chatrousse, A. P. ; Pouet, M. J. and Simonnin, M., Org. Magn. Reson., 1976, 8, 56.

[24] Terrier, F.; Goumont, R.; Hallé, J. C. and Pouet, M. J., J. Chem. Soc. Perkin Trans. 2. 1995, 1629.

[25] Martin, G.E.; Hadden, C.E. J. Nat. Prod. 2000, 63, 543.

[26] Levy, G.C.; Lichter, R.L. Nitrogen 15N NMR Spectroscopy, Wiley : New York, 1978. 


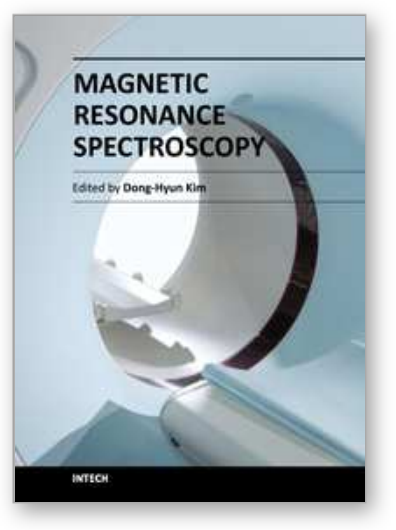

\author{
Magnetic Resonance Spectroscopy \\ Edited by Prof. Dong-Hyun Kim
}

ISBN 978-953-51-0065-2

Hard cover, 264 pages

Publisher InTech

Published online 02, March, 2012

Published in print edition March, 2012

Magnetic Resonance Spectroscopy (MRS) is a unique tool to probe the biochemistry in vivo providing metabolic information non-invasively. Applications using MRS has been found over a broad spectrum in investigating the underlying structures of compounds as well as in determining disease states. In this book, topics of MRS both relevant to the clinic and also those that are beyond the clinical arena are covered. The book consists of two sections. The first section is entitled 'MRS inside the clinic' and is focused on clinical applications of MRS while the second section is entitled 'MRS beyond the clinic' and discusses applications of MRS in other academic fields. Our hope is that through this book, readers can understand the broad applications that NMR and MRS can offer and also that there are enough references to guide the readers for further study in this important topic.

\title{
How to reference
}

In order to correctly reference this scholarly work, feel free to copy and paste the following:

M. Sebban, P. Sepulcri, C. Jovene, D. Vichard, F. Terrier and R. Goumont (2012). NMR Spectroscopy: A Useful Tool in the Determination of the Electrophilic Character of Benzofuroxans - Case Examples of the Reactions of Nitrobenzofuroxans with Dienes and Nucleophiles, Magnetic Resonance Spectroscopy, Prof. Dong-Hyun Kim (Ed.), ISBN: 978-953-51-0065-2, InTech, Available from:

http://www.intechopen.com/books/magnetic-resonance-spectroscopy/nmr-spectroscopy-a-useful-tool-in-thedetermination-of-the-electrophilic-character-of-benzofuroxans-

\section{INTECH}

open science | open minds

\section{InTech Europe}

University Campus STeP Ri

Slavka Krautzeka 83/A

51000 Rijeka, Croatia

Phone: +385 (51) 770447

Fax: +385 (51) 686166

www.intechopen.com

\section{InTech China}

Unit 405, Office Block, Hotel Equatorial Shanghai

No.65, Yan An Road (West), Shanghai, 200040, China

中国上海市延安西路65号上海国际贵都大饭店办公楼 405 单元

Phone: +86-21-62489820

Fax: $+86-21-62489821$ 
(C) 2012 The Author(s). Licensee IntechOpen. This is an open access article distributed under the terms of the Creative Commons Attribution 3.0 License, which permits unrestricted use, distribution, and reproduction in any medium, provided the original work is properly cited. 